\title{
Resistance to Thiophanate-Methyl in Botrytis cinerea Isolates From Californian Vineyards and Pistachio and Pomegranate Orchards
}

\author{
Hervé F. Avenot, ${ }^{\dagger}$ David P. Morgan, Joel Quattrini, and Themis J. Michailides ${ }^{\dagger}$ \\ Department of Plant Pathology, Kearney Agricultural Research and Extension Center, University of California, Davis, Parlier, CA \\ 93648
}

\begin{abstract}
In this study, a mycelial growth assay was used to evaluate the sensitivity to thiophanate-methyl of 144 Botrytis cinerea isolates (collection A) from Californian vineyards and pistachio and pomegranate orchards. Based on the effective concentration that inhibits $50 \%$ of growth $\left(\mathrm{EC}_{50}\right)$ values for mycelial growth inhibition on fungicide-amended media, $3,28,10$, and $58 \%$ of the isolates showed sensitivity $\left(\mathrm{SS} ; \mathrm{EC}_{50}<\right.$ $1 \mu \mathrm{g} / \mathrm{ml}$ ), low resistance (LR; $1<\mathrm{EC}_{50}<10 \mu \mathrm{g} / \mathrm{ml}$ ), weak resistance (WR; $10<\mathrm{EC}_{50}<50 \mu \mathrm{g} / \mathrm{ml}$ ), and high resistance $\left(\mathrm{HR} ; \mathrm{EC}_{50}>\right.$ $100 \mu \mathrm{g} / \mathrm{ml}$ ) toward thiophanate-methyl, respectively. The LR and HR phenotypes were observed in pistachio and pomegranate orchards, even though pomegranate was not sprayed with thiophanate-methyl. Sensitivity to thiophanate-methyl of a historical collection of $257 \mathrm{~B}$. cinerea iso-

percentages of thiophanate-methyl-resistant isolates were 50,72 , and $64 \%$ in the orchards in 1992, 2005, and 2006, respectively. A study of fitness components of selected thiophanate-methyl-resistant (LR, WR, and HR) and -sensitive (SS) isolates from collection A did not reveal any significant difference between them with respect to mycelial growth on fungicide-free media and pathogenicity on cultivar Crimson Seedless berries. Comparison of $\beta$-tubulin sequences from resistant and sensitive phenotypes revealed that a glutamic acid at position 198 was changed to alanine in all HR isolates and three LR isolates. The occurrence of thiophanate-methyl resistance in $B$. cinerea populations should be considered when designing spray programs against blossom and shoot blight of pistachio and gray mold of grape.
\end{abstract} lates (collection B) isolated from pistachio orchards in 1992, 2005, and 2006 was assessed on potato dextrose agar amended with thiophanatemethyl at the discriminatory concentration of $10 \mu \mathrm{g} / \mathrm{ml}$. Average
Keywords: chemical, disease management, fruit, fungi, tree fruits, trees, tree nuts
The ubiquitous fungus Botrytis cinerea Pers:Fr (teleomorph Botryotinia fuckeliana [de Bary] Whetzel) is responsible for serious pre- and postharvest diseases of various crops, including bunch rot in the field and gray mold of grapes in storage, blossom and shoot blight in pistachio, and gray mold of pomegranate in storage (Michailides 1991; Palou et al. 2013; Tedford et al. 2005). All three hosts suffer significant losses when the environmental or storage conditions are conducive to infections (Bolkan et al. 1984; Elmer and Michailides 2004; Michailides 1991; Ott 2004; Tedford et al. 2005). Although cultural practices play an important role in reducing the pathogen inoculum levels, successful prevention and control of gray mold in vineyards and Botrytis blossom blight in pistachio orchards rely heavily on the applications of fungicides (Adaskaveg et al. 2017; Billard et al. 2011; Leroux 2004; Panebianco et al. 2015).

The methyl benzimidazole carbamate (MBC) or benzimidazole fungicides are among the chemical classes currently available for gray mold control worldwide. They have a specific mode of action and bind to the $\beta$-tubulin subunits, thus preventing the nuclear division via inhibition of microtubule assembly during mitosis. Because of the specificity of their mode of action, MBC fungicides have a high risk of resistance development (Brent and Hollomon 1998; Topolovec-Pintarić 2011). Members of the MBC class include carbendazim, benomyl, and thiophanate-methyl, which were developed in the late 1960s (Leroux 2004). They have systemic and broad-spectrum activities, with excellent inhibitory action against mycelial growth

${ }^{\dagger}$ Corresponding authors: H. F. Avenot; hfavenot@ucdavis.edu, and T. J. Michailides; tjmichailides@ucanr.edu

Funding: We thank California Pistachio Research Board grant Res Agreem201302565 for financial support.

The author(s) declare no conflict of interest.

Accepted for publication 7 October 2019.

(C) 2020 The American Phytopathological Society and germ-tube elongation of Ascomycetes, especially Botrytis spp. (Leroux 2004; Topolovec-Pintarić 2011). Benzimidazole resistance problems have been associated with alterations in the binding sites on the $\beta$-tubulin protein and appeared in numerous fungi soon after their commercial use (Brent and Hollomon 1998; Davidse and Ishii 1995; Fungicide Resistance Action Committee 2012; Koenraadt et al. 1992; Leroux 2004; Topolovec-Pintarić 2011). Practical resistance in the field has been reported for these fungicides in several countries in many crops, including grapes and pistachios, thus resulting in their withdrawal from the market (Leroux 2004; Schüepp and Küng 1981; Topolovec-Pintarić 2011). Benomyl was the first MBC fungicide used to control gray mold in grape vineyards, but because of the development of resistance, it was withdrawn from the market. Instead, grape growers continue to use thiophanate-methyl for the control of pre- and postharvest gray mold in vineyards (Adaskaveg et al. 2017; Smilanick et al. 2010). In the case of pistachio, benomyl was used to control Botrytis blossom and shoot blight in 1988 for the first time, and it was very effective in controlling the disease in the early years of its use. A single application with benomyl (Benlate $50 \mathrm{~W})$ at bloom significantly reduced the blossom and shoot blight in pistachio orchards (Bolkan et al. 1984). These efficacy data were instrumental in obtaining a "Section 18" registration for use of benomyl as early as 1988 (Du Pont 1988). However, benomyl resistance problems in populations of the Botrytis shoot blight pathogen developed very soon after benomyl use on pistachios began (Teviotdale et al. 2002). As a result, benomyl has not been used for Botrytis blossom and shoot blight control in California pistachio for $>30$ years. With the withdrawal of benomyl from the market, more and more pistachio growers have used thiophanate-methyl as a replacement. Although thiophanate-methyl is currently registered in the United States for the control of pre- and postharvest gray mold in vineyards and Botrytis blossom and shoot blight in pistachio orchards, it has never been used in pomegranates.

Although MBCs have historically been part of chemical control programs used against gray mold in vineyards and pistachios in California, information on the occurrence, cross-resistance between benomyl and thiophanate-methyl, and extent and persistence of resistance to thiophanate-methyl is still lacking, especially in pistachio. The 
continued use of thiophanate-methyl in commercial pistachio and grape may prove unnecessary in situations where a very high increase or prevalence of resistant populations may occur. Therefore, monitoring of the frequencies of thiophanate-methyl resistance in $B$. cinerea populations in these crops is necessary to maintain an adequate and rational deployment of disease control programs. The usefulness and efficacy of MBC fungicides against Botrytis blossom and shoot blight and gray mold diseases are dependent on the timing and the application system. It also depends on a clear understanding of the ecological and molecular factors that affect development of $B$. cinerea resistance (Brent and Hollomon 1998; Smilanick et al. 2010) to these fungicides.

Therefore, the specific objectives of this study were to (i) determine and document the presence and extent of thiophanate-methyl resistance in California populations of $B$. cinerea collected from grape and pistachio fields with a history of benzimidazole usage; (ii) assess the sensitivity to thiophanate-methyl of $B$. cinerea isolates from unsprayed pomegranate orchards; (iii) assess the sensitivity to thiophanate-methyl of a historic population collected in previous years from pistachio orchards and analyze the cross-resistance pattern between thiophanate-methyl and benomyl; (iv) determine the molecular mechanism of thiophanate-methyl resistance in California isolates of B. cinerea; (v) assess whether or not resistance is associated with fitness costs in thiophanate-methyl-resistant phenotypes; and (vi) evaluate the efficacy of thiophanate-methyl (Topsin M) to control gray mold on detached grape berries.

\section{Materials and Methods}

Isolates collections. A collection of $144 \mathrm{~B}$. cinerea monosporic isolates (collection A) isolated between 2003 and 2014 from three hosts, namely pistachio $(n=74)$, grape $(n=58)$, and pomegranate $(n=12)$, was included in this study (Table 1). In addition, 257 single-spore $B$. cinerea isolates (collection B) collected from pistachio orchards in California (the United States) in 1992 (2 isolates), 2005 (91 isolates), and 2006 (164 isolates) were added (Table 2). Isolates from 2005 were collected from blighted shoots, which showed symptoms after wet spring weather. Samples from 2006 were isolated from dormant pistachio buds, and they were collected from 1 to 7 March 2006, except for in orchard 6, in which they were collected from male pistachio buds on 9 November 2006. Isolates from both collections $\mathrm{A}$ and $\mathrm{B}$ were maintained as spore suspensions in $30 \%$ glycerol at $-75^{\circ} \mathrm{C}$ until they were transferred and grown on petri dishes containing acidified $(2.5 \mathrm{ml}$ of $25 \%$ [ $\mathrm{vol} / \mathrm{vol}$ lactic acid per liter) Difco potato dextrose agar (PDA; $4.0 \mathrm{~g}$ of potato infusion, $20.0 \mathrm{~g}$ of dextrose, and $15 \mathrm{~g}$ agar per liter) and finally, incubated in the dishes at 22 to $24^{\circ} \mathrm{C}$ for 3 to 4 days.

Sensitivity of $B$. cinerea isolates (collection A) to thiophanatemethyl. The inhibitory effect of thiophanate-methyl against $B$. cinerea isolates was first determined by recording their radial growth on PDA media amended with the final concentrations of the fungicide at 0 (control), 1, 10, 50, and $100 \mu \mathrm{g}$ a.i./ml of medium. Maximal

Table 1. Origins of Botrytis cinerea isolates (collection A) used in this study classified by hosts and ordered by year of collection

\begin{tabular}{clcll}
\hline Host and number & \multicolumn{1}{c}{ City } & Year & County & \multicolumn{1}{c}{ State } \\
\hline Grape & & & & \\
4 & Ashville & 2003 & Buncombe & North Carolina \\
13 & Bakersfield & 2004 & Kern & California \\
19 & Reedley & 2005 & Fresno & California \\
21 & Parlier & 2005 & Fresno & California \\
1 & Bakersfield & 2005 & Kern & California \\
Pistachio & & & & \\
5 & - & 2006 & Glenn & California \\
1 & - & 2007 & Tulare & California \\
28 & Orland & 2010 & Glenn & California \\
40 & Shafter & 2011 & Kern & California \\
Pomegranate & & & & \\
1 & Dudley Ridge & 2013 & Kern & California \\
8 & Del Rey & 2013 & Fresno & California \\
2 & Dudley Ridge & 2014 & Kern & California \\
1 & Parlier & 2014 & Fresno & California \\
\hline
\end{tabular}

1070 Plant Disease /Vol. 104 No. 4 growth in thiophanate-methyl-amended media is defined as the diameter of the colony as obtained for the control plates (no fungicide), whereas no radial growth means total inhibitory effect of thiophanate-methyl. An increase of radial growth corresponded to a decrease of the inhibitory effect of thiophanate-methyl. Thiophanate-methyl (70\% WP; Elf Atochem North America, Inc.) was dissolved in water to prepare a stock solution at $10 \mathrm{mg}$ a.i./. $\mathrm{ml}$. To obtain fungicide-amended media at the abovespecified concentrations, aliquots from the stock solution were subsequently added to autoclaved media (at a temperature of $45^{\circ} \mathrm{C}$ ). Mycelial plugs (4-mm diameter) from 3-day-old colonies of each of the 144 isolates were taken using a cork borer and placed upside down in the center of thiophanate-methyl-amended and nonamended plates. After 3 days of incubation, the diameter of the colony on each plate was measured in two perpendicular directions. Two replicate plates for each isolate and per each fungicide concentration were used, and the experiment was repeated twice. The effective concentration that inhibits $50 \%$ of growth $\left(\mathrm{EC}_{50}\right)$ of each isolate was calculated using linear regression of probit-transformed relation inhibition (1-RG) on $\log _{10}$-transformed thiophanate-methyl concentration. Normality of the $\mathrm{EC}_{50}$ frequency distribution was assessed using the

Table 2. Frequencies of Botrytis cinerea thiophanate-methyl (Topsin M)resistant isolates (collection B) collected from 14 pistachio orchards during 1992, 2005, and 2006 ordered by year of collection

\begin{tabular}{|c|c|c|c|}
\hline \multirow[b]{2}{*}{$\begin{array}{l}\text { Year collected, } \\
\text { county, and } \\
\text { orchard }\end{array}$} & \multicolumn{2}{|c|}{ Number of isolates } & \multirow[b]{2}{*}{$\begin{array}{l}\text { Frequency of } \\
\text { thiophanate-methyl } \\
\text { resistance }(\%)\end{array}$} \\
\hline & Tested & $\begin{array}{l}\text { Resistant to } \\
\text { thiophanate-methyl } \\
\text { at } 10 \mu \mathrm{g} / \mathrm{ml}\end{array}$ & \\
\hline \multicolumn{4}{|l|}{1992} \\
\hline \multicolumn{4}{|l|}{ Fresno } \\
\hline 1 & 2 & 1 & 50 \\
\hline \multicolumn{4}{|l|}{2005} \\
\hline \multicolumn{4}{|l|}{ Fresno } \\
\hline 1 & 6 & 4 & 67 \\
\hline 2 & 5 & 3 & 60 \\
\hline 3 & 5 & 3 & 60 \\
\hline 4 & 2 & 1 & 50 \\
\hline \multicolumn{4}{|l|}{ Madera } \\
\hline 5 & 23 & 15 & 65 \\
\hline 6 & 12 & 7 & 58 \\
\hline 7 & 11 & 5 & 45 \\
\hline \multicolumn{4}{|l|}{ Kern } \\
\hline 8 & 2 & 1 & 50 \\
\hline 9 & 25 & 25 & 100 \\
\hline \multicolumn{4}{|l|}{2006} \\
\hline \multicolumn{4}{|l|}{ Butte } \\
\hline 1 & 14 & 4 & 29 \\
\hline \multicolumn{4}{|l|}{ Colusa } \\
\hline 2 & 14 & 10 & 71 \\
\hline \multicolumn{4}{|l|}{ Fresno } \\
\hline 3 & 9 & 1 & 11 \\
\hline \multicolumn{4}{|l|}{ Glenn } \\
\hline 4 & 13 & 0 & 0 \\
\hline 5 & 14 & 4 & 29 \\
\hline 6 & 20 & 20 & 100 \\
\hline \multicolumn{4}{|l|}{ Kern } \\
\hline 7 & 7 & 4 & 57 \\
\hline 8 & 14 & 13 & 93 \\
\hline 9 & 14 & 13 & 93 \\
\hline \multicolumn{4}{|l|}{ Madera } \\
\hline 10 & 12 & 10 & 83 \\
\hline 11 & 12 & 8 & 67 \\
\hline \multicolumn{4}{|l|}{ Kings } \\
\hline 12 & 15 & 13 & 87 \\
\hline \multicolumn{4}{|l|}{ Tulare } \\
\hline 13 & 5 & 4 & 80 \\
\hline \multicolumn{4}{|l|}{ Yolo } \\
\hline 14 & 1 & 1 & 100 \\
\hline
\end{tabular}


Shapiro-Wilk test in SAS (version 9.2; SAS Inc.). Isolates were classified as sensitive (SS; $\left.\mathrm{EC}_{50}<1 \mu \mathrm{g} / \mathrm{ml}\right)$, low resistance $\left(\mathrm{LR} ; 1<\mathrm{EC}_{50}<\right.$ $10 \mu \mathrm{g} / \mathrm{ml}$ ), weak resistance (WR; $10<\mathrm{EC}_{50}<50 \mu \mathrm{g} / \mathrm{ml}$ ), moderate resistance $\left(50<\mathrm{EC}_{50}<100 \mu \mathrm{g} / \mathrm{ml}\right)$, and high resistance $\left(\mathrm{HR} ; \mathrm{EC}_{50}>\right.$ $100 \mu \mathrm{g} / \mathrm{ml}$ ) to thiophanate-methyl based on their $\mathrm{EC}_{50}$ values.

Evaluation of $B$. cinerea isolates (collection $B$ ) for resistance to thiophanate-methyl and benomyl at the discriminatory concentration of $10 \mu \mathrm{g} / \mathrm{ml}$. Based on Leroux (2004), the single discriminatory doses for thiophanate-methyl and benomyl at $10 \mu \mathrm{g} / \mathrm{ml}$ were adequate to distinguish between $B$. cinerea fungicide-resistant and -sensitive isolates. In radial growth test, none of the fungicidesensitive isolates in collection A grew $>6 \%$ in diameter relative to the control check (PDA at $0 \mu \mathrm{g} / \mathrm{ml}$ ) when tested on PDA plates amended at this concentration. Collection B of 257 isolates was screened for resistance against thiophanate-methyl and benomyl with mycelial growth tests using a single discriminatory dose for each fungicide established at $10 \mu \mathrm{g} / \mathrm{ml}$. Twenty-five isolates, which were randomly selected from pistachio orchards in Fresno, Madera, and Kern Counties, were tested for both thiophanate-methyl and benomyl sensitivities. Stock solutions containing $10 \mathrm{mg}$ a.i./ml of thiophanatemethyl and benomyl were prepared using formulated products of Topsin M 70 WSB (70\% thiophanate-methyl; United Phosphorus Inc.) and Benlate 50 WP (50\% benomyl; du Pont de Nemours). Products were dissolved in sterile water, and aliquots were added to autoclaved PDA at a temperature of $50^{\circ} \mathrm{C}$ to produce fungicide-amended media with the desired discriminatory concentration of $10 \mu \mathrm{g} / \mathrm{ml}$. Nonamended media were used as controls. The $257 \mathrm{~B}$. cinerea isolates (collection B) were grown on PDA. Then, 5-mm plugs were transferred to three replicate plates of PDA amended with $10 \mu \mathrm{g} / \mathrm{ml}$ thiophanate-methyl and/or benomyl. The growth of the colony was measured after 3 days. Based on the results from radial growth tests performed for isolates from collection $\mathrm{A}$, isolates were considered resistant if their radial growth on benzimidazole fungicideamended media exceeded $88 \%$ of the fungicide-free media; they were considered sensitive or intermediate resistant if relative growth was $<6 \%$ or between 6 and $88 \%$, respectively. For each orchard, the frequency or percentage of fungicide resistance in each year was calculated as the ratio of the number of resistant isolates detected to the total number of isolates recovered that year.

Fitness of thiophanate-methyl-resistant isolates and efficacy of thiophanate-methyl (Topsin M). To assess whether the identified thiophanate-methyl-resistant phenotypes were associated with fitness costs, the radial growth rate on fungicide nonamended media and pathogenicity on detached grape berries were measured. Mycelial plugs of 10 sensitive (SS) and 25 resistant isolates from collection A (10 LR, $5 \mathrm{WR}$, and $10 \mathrm{HR}$ ) were excised as described in previous sections and placed in the center of two replicate PDA plates. After 3 days of incubation $\left(22 \pm 2^{\circ} \mathrm{C}\right)$, the diameter of the colony was recorded in each plate, and the experiment was repeated twice. Differences between growth rates of resistant versus sensitive isolates were analyzed using PROC GLM (SAS 9.2).

Pathogenicity of six selected isolates from collection A (2 SS, 2 LR, and 2 HR phenotypes) on untreated grape berries and efficacy of thiophanate-methyl-treated detached grape berries were evaluated as previously described (Avenot et al. 2018). Table grape berries of the cultivar Crimson Seedless were collected from an experimental vineyard at Kearney Agricultural Research and Extension Center in Parlier, California. Two thiophanate-methyl-sensitive isolates (SS; G-01-C05 and Pi-06-J55), two LR isolates (G-05-B44 and G02-G36), and two thiophanate-methyl isolates with HR level (Po$10 \mathrm{BC}$ and Pi-06-K45) to thiophanate-methyl were tested for their ability to cause gray mold on detached berries in the absence or presence of thiophanate-methyl treatment as previously described (Avenot et al. 2018). Briefly, grape berries were disinfected in $10 \%$ household bleach (5\% sodium hypochlorite) and $0.01 \%$ Tween 20 (Fisher 20 Scientific) for $4 \mathrm{~min}$. After disinfection, the berries were put on plastic screen trays in crispers using surgical gloves. Two replicate crispers were used for the treatment and nontreatment replications, and the experiment was repeated twice. In each crisper, 18 berries were used for each isolate in each phenotype group. Prior to inoculation with gray mold, the berries were punctured with a needle of 0.25 -mm diameter and then, sprayed to run off at the recommended label rate of thiophanate-methyl $4.5 \mathrm{FL}$ (at $0.78 \mathrm{ml} / \mathrm{liter}$ ) using a handheld sprayer. Untreated control berries were sprayed with deionized, autoclaved water. When the fruit surface had dried off, wounded berries were inoculated using a 10- $\mu$ l droplet of a spore suspension $\left(1 \times 10^{5}\right.$ conidia per $\left.1 \mathrm{ml}\right)$ of the pathogen. Pathogenicity (severity of decay of berries) and efficacy of the fungicide were determined using a 0 to 4 scale system (Avenot et al. 2018). Gray mold severities were compared among phenotypes using PROC GLM (procedure in SAS 9.2) followed by means separations using Fisher's LSD at $P=0.05$.

Partial sequencing and sequence analysis of $\beta$-tubulin gene from $B$. cinerea isolates. The specific oligonucleotide primers bctubR (5'-AAAATGGCAGAGCATGTCAA-3') and bctubF (5'AGGTACCATGGATGCTGTCC-3') (Ziogas et al. 2009) were used to amplify a 751-bp partial genomic DNA (codons 109 to 418) to detect the possible mutations in thiophanate-methyl-resistant strains. Fifty-one thiophanate-methyl-resistant isolates and five (only two are shown in Table 3) thiophanate-methyl-sensitive isolates from collection A were selected and screened for mutation (Table 3). The PCR run parameters $\left(25\right.$ cycles of $94^{\circ} \mathrm{C}$ for $30 \mathrm{~s}, 50^{\circ} \mathrm{C}$ for 30 $\mathrm{s}$, and $72^{\circ} \mathrm{C}$ for $1 \mathrm{~min}$ ) were the same as described by Ziogas et al. (2009), except for the initial denaturation step, which was set at $95^{\circ} \mathrm{C}$ for $3 \mathrm{~min}$. Genomic DNA from thiophanate-methyl-sensitive and thiophanate-methyl-resistant isolates were extracted using the Fast DNA SPIN Kit (MP Biomedicals) according to the manufacturer's instructions. PCR reactions were prepared in a 50- $\mu 1$ final volume containing $3 \mu \mathrm{l}$ of DNA template (1/10 diluted), $25 \mu \mathrm{l}$ of PCR Master Mix $2 \times$ (Promega), $1 \mu l$ of forward and reverse primers at $10 \mu \mathrm{M}$, and $20 \mu \mathrm{l}$ of nuclease-free water. Ten microliters of the PCR products were mixed with $2 \mu l$ of loading dye plus GR (10 $\mu \mathrm{l}$ of Gel Red in 1,000 $\mu \mathrm{l}$ of loading dye $6 \times$ ) and examined by electrophoresis in a $1.5 \%$ agarose gel in $1 \times$ Tris-acetate buffer. PCR products were subsequently purified using the ExoSAP-IT PCR Purification Kit (USB, Affymetrix; USB Corporation) and sequenced in both directions, and the resulting sequences were analyzed with DNASTAR sequence analysis software (DNASTAR, Inc.) as previously described (Avenot et al. 2018).

\section{Results}

Effect of thiophanate-methyl on mycelial growth of $B$. cinerea isolates (collection A). Results of the in vitro sensitivity tests on PDA media amended with thiophanate-methyl revealed that the 144 $B$. cinerea isolates (collection A) could be divided into four thiophanate-methyl sensitivity phenotypes (Fig. 1). Most of the B. cinerea isolates from pistachio and pomegranate displayed the HR and LR phenotypes, whereas most of the grape isolates had the LR phenotype. Four (7\%) grape isolates were sensitive to thiophanate-methyl, whereas 32 (55\%), $9(16 \%)$, and 13 (22\%) had the LR, WR, and HR phenotypes, respectively. Among the 74 pistachio isolates, one (1\%) was sensitive to thiophanate-methyl, and five (7\%) isolates were LR, whereas six (8\%) isolates were WR. The other $62(84 \%)$ pistachio isolates displayed the HR phenotype. No pomegranate isolate was sensitive to thiophanate-methyl. Three $(25 \%)$ isolates showed LR, whereas the other nine $(75 \%)$ isolates were HR strains.

Screening of $B$. cinerea isolates (collection $B$ ) for resistance to thiophanate-methyl and cross-resistance with benomyl. Among 91 isolates of B. cinerea (collection B) collected in 2005 from several pistachio orchards in three counties, $72 \%$ of them were resistant to thiophanate-methyl at $10 \mu \mathrm{g} / \mathrm{ml}$ (Table 2). Resistant isolates were detected in all three counties, and their percentages varied from 45 to $100 \%$ in the sampled orchards. In all but one orchard, $>50 \%$ of the isolates were resistant to thiophanate-methyl.

In the 1992 population, among the two isolates collected, one (50\%) was resistant to thiophanate-methyl (Table 2). Of the $164 \mathrm{~B}$. cinerea isolates collected in 2006, $64 \%$ were resistant to $10 \mu \mathrm{g} / \mathrm{ml}$ of thiophanate-methyl. Resistant isolates from 2006 were detected in all counties tested. We detected a wide percentage of thiophanate-methyl-resistant isolates varying from 0 to $100 \%$. Four of 
the 14 orchards had $<30 \%$ resistant isolates, whereas the percentage of resistant isolates in the other 10 orchards ranged from 57 to $100 \%$ (Table 2).

There was a high correlation $\left(R^{2}=0.96\right)$ between resistance to benomyl and thiophanate-methyl when relative growth of the same 25 isolates for both fungicides was compared using Pearson correlation

Table 3. Sensitivity (effective concentration that inhibits $50 \%$ of growth $\left[\mathrm{EC}_{50}\right]$ values) of Botrytis cinerea isolates from three hosts to thiophanatemethyl and amino acid alterations in the $\beta$-tubulin target protein

\begin{tabular}{|c|c|c|c|}
\hline \multirow[b]{2}{*}{ Isolate code ca $^{\mathbf{a}}$} & \multicolumn{2}{|c|}{$\begin{array}{c}\text { Sensitivity to } \\
\text { thiophanate-methyl }\end{array}$} & \multirow{2}{*}{$\begin{array}{c}\text { Amino acid at position } \\
198 \text { in } \beta \text {-tubulin }\end{array}$} \\
\hline & $\mathbf{E C}_{50}$ values & Phenotypes $^{b}$ & \\
\hline G-01-A03 & $>100$ & HR & $\mathrm{A}$ \\
\hline G-01-B13 & 2.14 & LR & A \\
\hline G-01-C03 & 7.98 & LR & E \\
\hline G-01-C13 & $>100$ & HR & A \\
\hline G-01-C14 & 4.69 & LR & $\mathrm{E}$ \\
\hline G-01-C15 & 7.76 & LR & $\mathrm{E}$ \\
\hline G-01-C18 & $>100$ & HR & A \\
\hline G-01-C19 & 7.98 & LR & E \\
\hline G-01-C20 & $>100$ & HR & A \\
\hline G-01-C23 & $>100$ & HR & A \\
\hline G-01-C24 & $>100$ & HR & A \\
\hline G-02-G36 & 5.67 & LR & A \\
\hline G-05-B27 & 4.69 & LR & $\mathrm{E}$ \\
\hline G-05-B31 & $>100$ & HR & A \\
\hline G-05-B38 & 0.19 & SS & $\mathrm{E}$ \\
\hline G-05-B39 & 37.64 & WR & $\mathrm{E}$ \\
\hline G-05-B40 & 1.89 & LR & $\mathrm{E}$ \\
\hline G-05-B43 & 4.69 & LR & $\mathrm{E}$ \\
\hline G-05-B44 & 1.59 & LR & A \\
\hline Pi-04-K98 & 7.48 & LR & $\mathrm{E}$ \\
\hline Pi-04-L05 & $>100$ & HR & A \\
\hline Pi-04-L13 & $>100$ & HR & A \\
\hline Pi-04-L15 & $>100$ & HR & A \\
\hline Pi-04-L17 & 4.69 & LR & $\mathrm{E}$ \\
\hline Pi-04-L18 & $>100$ & HR & A \\
\hline Pi-04-L20 & 19.29 & WR & $\mathrm{E}$ \\
\hline Pi-04-L21 & 20.43 & WR & $\mathrm{E}$ \\
\hline Pi-04-L27 & 11.75 & WR & $\mathrm{E}$ \\
\hline Pi-04-L30 & $>100$ & HR & A \\
\hline Pi-06-J55 & 0.54 & SS & $\mathrm{E}$ \\
\hline Pi-06-J57 & $>100$ & HR & A \\
\hline Pi-06-J59 & $>100$ & HR & A \\
\hline Pi-06-J66 & $>100$ & HR & A \\
\hline Pi-06-J67 & $>100$ & HR & A \\
\hline Pi-06-J68 & $>100$ & HR & A \\
\hline Pi-06-J69 & $>100$ & HR & A \\
\hline Pi-06-J71 & $>100$ & HR & A \\
\hline Pi-06-K17 & $>100$ & HR & A \\
\hline Pi-06-K21 & $>100$ & HR & A \\
\hline Pi-06-K22 & $>100$ & HR & A \\
\hline Pi-06-K31 & $>100$ & HR & A \\
\hline Pi-06-K32 & $>100$ & HR & A \\
\hline Pi-06-K38 & $>100$ & HR & A \\
\hline Pi-06-K42 & $>100$ & HR & A \\
\hline Pi-06-K43 & $>100$ & HR & A \\
\hline $\mathrm{Pi}-06-\mathrm{K} 45$ & $>100$ & HR & A \\
\hline Pi-06-K64 & 13.63 & WR & $\mathrm{E}$ \\
\hline Pi-06-K66 & $>100$ & HR & A \\
\hline Pi-06-K71 & $>100$ & HR & A \\
\hline Po-10 BC & $>100$ & HR & A \\
\hline Po-25 BC & 6.65 & LR & $\mathrm{E}$ \\
\hline Po-7L-74 & $>100$ & HR & $\mathrm{A}$ \\
\hline Po-7L-75 & 4.69 & LR & $\mathrm{E}$ \\
\hline
\end{tabular}

${ }^{a} \mathrm{G}$, grape; $\mathrm{Pi}$, pistachio; Po, pomegranate.

${ }^{\mathrm{b}}$ HR, high resistance; LR, low resistance; SS, sensitive; WR, weak resistance. c A, Ala; E, Glu. analysis. A $t$ test showed no difference between the growth rate of the same $B$. cinerea isolates in media amended with thiophanate-methyl $(70.3 \pm 46.99 \%)$ or benomyl $(70.3 \pm 48.55 \%)$. Thus, isolates that developed resistance to benomyl in the past (when benomyl was used in pistachios) were also resistant to thiophanate-methyl. The same trends were observed for the fungicide-sensitive isolates. In addition, isolates were either HR $(52 \%)$ or very sensitive $(20 \%)$ to these two fungicides.

Fitness of $B$. cinerea thiophanate-methyl-resistant isolates and efficacy of thiophanate-methyl in controlling gray mold. Diameter of the mycelial growth on unamended PDA medium was measured for selected thiophanate-methyl-resistant and -sensitive phenotypes from the three hosts as identified in collection A; 10 thiophanate-methyl-sensitive isolates, 10 with LR, 5 with WR, and 10 displaying HR were used, but the mean radial growth values among phenotype groups were not significantly different.

The ability of two isolates selected from each of the three phenotype classes (SS, LR, and HR) to cause gray mold was evaluated on thiophanate-methyl-treated and nontreated grape berries. As identified in the mycelial growth tests, these phenotype classes correspond to an increased level of resistance. Because there was no significant difference in gray mold severities between the experiments and within phenotype, the data from the two experiments were combined for statistical analysis.

In the absence of thiophanate-methyl treatment, our results demonstrated that the two selected thiophanate-methyl-sensitive isolates (SS; G-01-C05 and Pi-06-J55) caused gray mold on untreated grape berries (Fig. 2). Different levels of virulence were found for the resistant phenotypes (Fig. 2). Gray mold severity $(1.10 \pm 0.07)$ for the two LR isolates (G-05-B44 and G-02-G36) on the untreated berries was significantly lower than that caused by the SS $(3.75 \pm 0.19)$ isolates, with a significant difference at $P<0.0001$. Although a fitness cost was observed for the LR phenotype, it was not the case for the two thiophanate-methyl isolates with HR level (Po-10 BC and Pi-597 06-K45). Gray mold severity caused by this HR phenotype (3.66 \pm $0.05)$ on untreated grape berries was similar to that obtained for the SS phenotype (Fig. 2), with no significant differences $(P=0.16)$.

When thiophanate-methyl was applied on the berries prior to the inoculation, gray mold severity caused by the two SS isolates decreased significantly $(P<0.0001)$ from class 4 to class 2 (Fig. 2). For G-05-B44 LR isolate, disease severity in nontreated berries was significantly lower than in thiophanate-methyl-treated berries. For G-02-G36 LR isolate, there was no significant differences in values between thiophanate-methyl-treated and nontreated berries. However, disease severity $(1.28 \pm 0.24)$ of the LR isolates was significantly lower than that of the HR isolates $(3.84 \pm 0.06)$ in the presence of thiophanate-methyl $(P<0.0001)$. In contrast, preventative treatment with thiophanate-methyl did not control gray mold caused by the HR phenotype (Fig. 2). There was no significant difference $(P=0.29)$ in disease severity in the absence or presence of thiophanate-methyl.

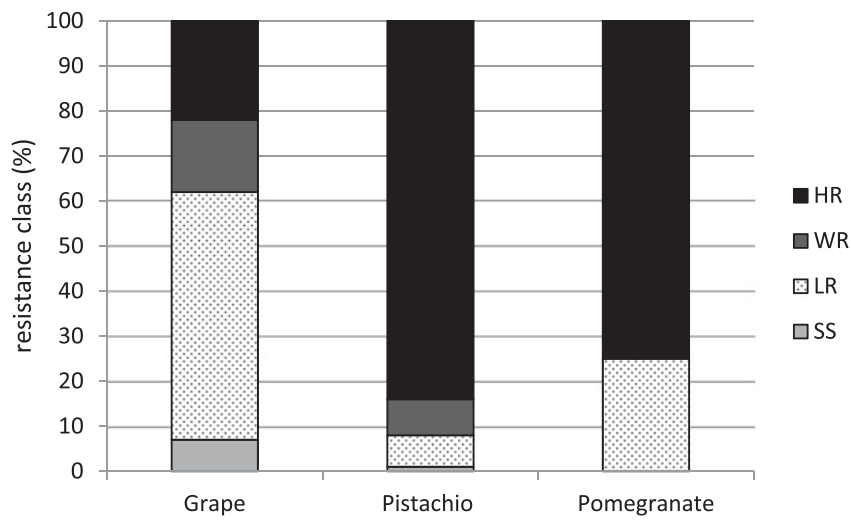

Fig. 1. Frequencies of Botrytis cinerea phenotypes from three hosts with different sensitivities to thiophanate-methyl. HR, high resistance; LR, low resistance; SS, sensitive; WR, weak resistance. 
Detection of mutations associated with thiophanate-methyl resistance in B. cinerea isolates. A portion of the $\beta$-tubulin gene (codons 109 to 418 ), which is known to contain mutations conferring resistance to benzimidazole (Ziogas et al. 2009), was sequenced from 51 thiophanate-methyl-resistant and 2 thiophanate-methyl-sensitive isolates. Analysis of the screened sequences of the selected 53

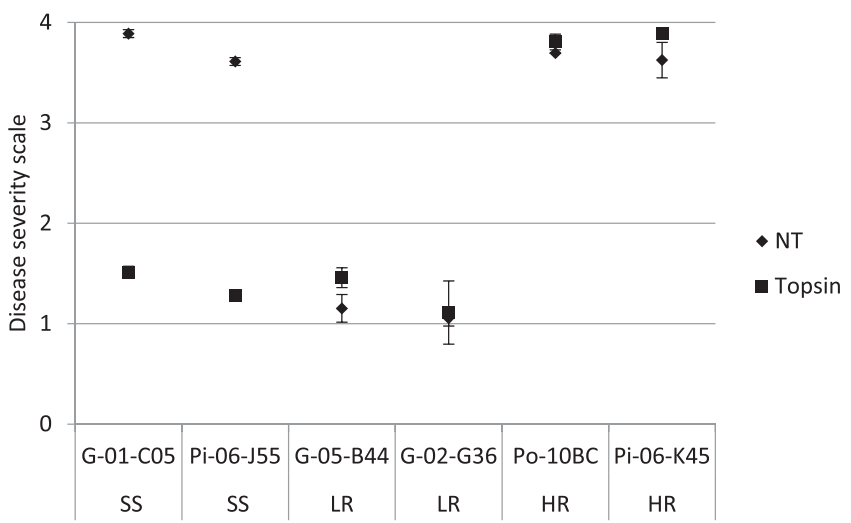

Fig. 2. Pathogenicity of Botrytis cinerea phenotypes on grape berries and efficacy of Topsin M in controlling gray mold caused by thiophanate-methyl-sensitive and -resistant isolates. Lines represent gray mold severity (average of three replications) using a 0 to 4 scale system. HR, high resistance; LR, low resistance; NT, nontreated; SS, sensitive. isolates showed the presence of the characteristic amino acid (glutamic acid at position 198 and phenylalanine at position 200) (Fig. 3) as observed in benzimidazole-sensitive fungal species (Koenraadt et al. 1992). Based on the sequencing of the 53 isolates, all B. cinerea isolates with the HR phenotype ( 32 isolates) and 3 isolates with the LR phenotype contained a single-amino acid substitution at position 198 resulting in the replacement of glutamic acid (GAG) with alanine (GCG) identified in all remaining isolates with HS and LR phenotypes (Fig. 3 and Table 3). No WR isolates presented this mutation. No substitutions in codons of F200 or L240, which are known to be involved in MBC resistance in other fungal species (Koenraadt et al. 1992; Ma and Michailides 2005a), were observed in any of these phenotypes (Fig. 3).

\section{Discussion}

Benzimidazoles were the first site-specific fungicides used against $B$. cinerea, but resistance to these fungicides was detected only a few years after their commercialization, causing management problems in the field in many cases. Benzimidazole-resistant isolates have been found in $>90$ different pathogens in several crops throughout the world (Fungicide Resistance Action Committee 2012; Stehmann and De Waard 1996). In this study, we identified $B$. cinerea isolates showing low to high levels of resistance to the benzimidazole fungicides in pistachio, grape, and pomegranate in California. More isolates displaying the highly resistant phenotype were especially detected among pistachio isolates. The high frequency of thiophanate-methyl- and benomyl-resistant isolates in California pistachio
Pi- $06-J 55$

$\mathrm{Pi}-04-\mathrm{L} 20$

$\mathrm{G}-05-\mathrm{B} 38$

$\mathrm{G}-01-\mathrm{A} 03$

$\mathrm{Pi}-04-\mathrm{L} 13$

$\mathrm{G}-01-\mathrm{B} 13$

Pi- $06-J 55$

$\mathrm{Pi}-04-\mathrm{L} 20$

$\mathrm{G}-05-\mathrm{B} 38$

$\mathrm{G}-01-\mathrm{A} 03$

$\mathrm{Pi}-04-\mathrm{L} 13$

$\mathrm{G}-01-\mathrm{B} 13$

$\mathrm{Pi}-06-\mathrm{J} 55$

$\mathrm{Pi}-04-\mathrm{L} 20$

$\mathrm{G}-05-\mathrm{B} 38$

$\mathrm{G}-01-\mathrm{A} 03$

$\mathrm{Pi}-04-\mathrm{L} 13$

$\mathrm{G}-01-\mathrm{B} 13$

$\mathrm{Pi}-06-\mathrm{J} 55$
$\mathrm{P} i-04-\mathrm{L} 20$
$\mathrm{G}-05-\mathrm{B} 38$
$\mathrm{G}-01-\mathrm{A} 03$
$\mathrm{P} i-04-\mathrm{L} 13$
$\mathrm{G}-01-\mathrm{B} 13$
HFVFGQSGAGNNWAKGHYTEGAELVDQVLDVVRREAEGCDCLQGFQITHSLGGGTGAGMG HFVFGQSGAGNNWAKGHYTEGAELVDQVLDVVRREAEGCDCLQGFQITHSLGGGTGAGMG HFVFGQSGAGNNWAKGHYTEGAELVDQVLDVVRREAEGCDCLQGFQITHSLGGGTGAGMG HFVFGQSGAGNNWAKGHYTEGAELVDQVLDVVRREAEGCDCLQGFQITHSLGGGTGAGMG HFVFGQSGAGNNWAKGHYTEGAELVDQVLDVVRREAEGCDCLQGFQITHSLGGGTGAGMG HFVFGQSGAGNNWAKGHYTEGAELVDQVLDVVRREAEGCDCLQGFQITHSLGGGTGAGMG

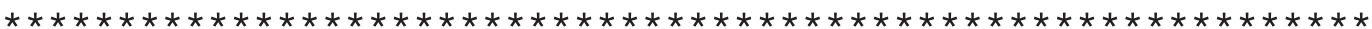

TLLISKIREEFPDRMMATFSVVPSPKVSDTVVEPYNATLSVHQLVENSDETFCIDNEALY TLLISKIREEFPDRMMATFSVVPSPKVSDTVVEPYNATLSVHQLVENSDETFCIDNEALY TLLISKIREEFPDRMMATFSVVPSPKVSDTVVEPYNATLSVHQLVENSDETFCIDNEALY TLLISKIREEFPDRMMATFSVVPSPKVSDTVVEPYNATLSVHQLVENSDATFCIDNEALY TLLISKIREEFPDRMMATFSVVPSPKVSDTVVEPYNATLSVHQLVENSDATFCIDNEALY TLLISKIREEFPDRMMATFSVVPSPKVSDTVVEPYNATLSVHQLVENSDATFCIDNEALY

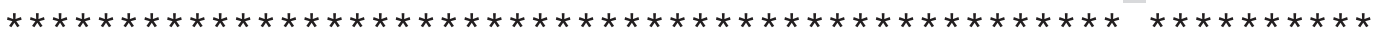

DICMRTLKLSNPSYGDLNHLVSAVMSGVTTCLRFPGQLNSDLRKLAVNMVPFPRLHFFMV DICMRTLKLSNPSYGDLNHLVSAVMSGVTTCLRFPGQLNSDLRKLAVNMVPFPRLHFFMV DICMRTLKLSNPSYGDLNHLVSAVMSGVTTCLRFPGQLNSDLRKLAVNMVPFPRLHFFMV DICMRTLKLSNPSYGDLNHLVSAVMSGVTTCLRFPGQLNSDLRKLAVNMVPFPRLHFFMV DICMRTLKLSNPSYGDLNHLVSAVMSGVTTCLRFPGQLNSDLRKLAVNMVPFPRLHFFMV DICMRTLKLSNPSYGDLNHLVSAVMSGVTTCLRFPGQLNSDLRKLAVNMVPFPRLHFFMV

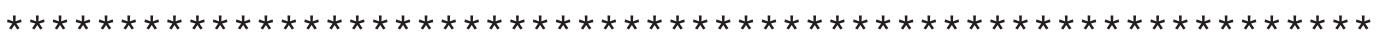

GFAPLTSRGAHSFRAVTVPELTQQMYDPKNMMAASDFRNGRYLTCXGHF GFAPLTSRGAHSFRAVTVPELTQQMYDPKNMMAASDFRNGRYLTCXGHF GFAPLTSRGAHSFRAVTVPELTQQMYDPKNMMAASDFRNGRYLTCXGHF GFAPLTSRGAHSFRAVTVPELTQQMYDPKNMMAASDFRNGRYLTCXGHF GFAPLTSRGAHSFRAVTVPELTQQMYDPKNMMAASDFRNGRYLTCXGHF GFAPLTSRGAHSFRAVTVPELTQQMYDPKNMMAASDFRNGRYLTCXGHF

Fig. 3. Alignment of partial $\beta$-tubulin amino acid sequences from Botrytis cinerea isolates. The amino acid at position 198 is boxed, and the gray shading indicates the mutation responsible for the E198A substitution. G-01-A03 and Pi-04-L13 (high resistance), G-01-B13 (low resistance), G-05-B38 and Pi-06-J55 (sensitive), and Pi-04-L20 (weak resistance) are representative isolates of the identified phenotypes. G, grape; Pi, pistachio. 
may be because of widespread use of Benlate and then, Topsin M. Benzimidazole fungicides were used for the control of Botrytis blossom and shoot blight in 1988 for the first time, and they had effectively controlled the disease in the early years following their introduction. However, it has been a long time since resistance of $B$. cinerea to benomyl has been reported (Teviotdale et al. 2002). Following the registration of benomyl for use on pistachios in the spring of 1988 (Du Pont 1988), growers started using it widely. According to University of California farm advisors, 10 to $15 \%$ of the growers in central and southern California and 75 to $100 \%$ of the growers in northern California had been applying a protective spray of benomyl on pistachio since its registration and until this fungicide was cancelled for any agricultural use and withdrawn from the market. High proportions of these isolates collected in commercial pistachio orchards in California in 1992, 2005, and 2006 were resistant to thiophanate-methyl and showed a crossresistance pattern with benomyl. Cross-resistance between the MBC fungicides thiophanate-methyl and benomyl has been reported in several pathogens, including Helminthosporium solani, Didymella bryoniae, and Colletotrichum cereale (Cunha and Rizzo 2003; Keinath 2002; Wong et al. 2008).

The presence of $B$. cinerea phenotypes with different levels of resistance to thiophanate-methyl as found in our study suggested the occurrence of different mutations in the $\beta$-tubulin gene, which may result in different binding affinities of benzimidazole to their target protein (Albertini et al. 1999; Koenraadt et al. 1992; Ma et al. 2003; Yarden and Katan 1993). Our analysis of the polymorphism within $\beta$-tubulin sequences from resistant and sensitive phenotypes showed the presence of a nonsynonymous single-nucleotide polymorphism at codon 198. This resulted in the substitution of a glutamic acid by an alanine that was strongly correlated with HR to thiophanate-methyl in B. cinerea isolates from all three hosts and that was also associated with benzimidazole resistance in several fungal plant pathogens, including $B$. cinerea (Albertini et al. 1999; Koenraadt et al. 1992; Luo et al. 2007; Ma and Michailides 2005a). No additional changes were identified in the sequenced portion of the $\beta$-tubulin. Curiously, no mutations were present at codons 167,200 , or 240, which had been shown to confer MBC resistance in other fungal species (Koenraadt et al. 1992; Leroux et al. 2002a, b; Ma and Michailides 2005a; Yarden and Katan 1993; Ziogas et al. 2009). No mutation was found in the $\beta$-tubulin gene of WR phenotypes, whereas only three LR phenotype had the E198A mutation. The basis for the weak and low levels of resistance of $B$. cinerea to thiophanate-methyl remains unclear, but as our results suggested, it seems unrelated to variations to the $\beta$-tubulin region that are responsible for high level of resistance to thiophanate-methyl. Analysis of the $\beta$-tubulin gene sequence in Monilinia fructicola revealed that a single-point mutation located at codon $6(\mathrm{CAT})$ resulting in the replacement of histidine by tyrosine (TAT) was associated with LR level to benzimidazoles in all of the LR isolates collected across different years from different locations (Ma et al. 2003). Because it is difficult to explain differences in the levels of resistance to a fungicide based on a single mutation, it seems, therefore, possible that other alterations could be present in another region of the $\beta$-tubulin gene that was not sequenced in this study. Moreover, the existence of a different mechanism of resistance cannot be ruled out.

The intensive use of benzimidazoles over the last 30 years combined with the ability of $B$. cinerea to develop resistance to fungicides and the high fitness of the benzimidazole-resistant isolates are all contributing factors that led to practical resistance in the field to these fungicides (Koenraadt et al. 1992; Leroux 2004). Our study of fitness components in $B$. cinerea thiophanate-methyl-sensitive and-resistant phenotypes showed that there were no fitness penalties associated with HR with regard to mycelial growth or pathogenicity. Our finding is in agreement with previous studies that showed that benomyl-resistant isolates of many fungal species in several crops throughout the world were as fit as benomyl-sensitive isolates (De Waard et al. 1993; Leroux 2004; Stehmann and De Waard 1996; Staub 1991). In most cases, benzimidazole resistance has been characterized by its long persistence in the field, even many years after the use of these fungicides was stopped (Georgopoulos and Skylakakis 1986; Koenraadt et al. 1992; Leroux 2004). The fact that isolates from our historical collection, which contains isolates recovered as early as 1992 from pistachio orchards, were able to grow at the discriminatory dose of $10 \mu \mathrm{g}$ a.i./ml of benomyl may suggest stability and lack of fitness costs associated with benzimidazole resistance. In this study, almost all of the $B$. cinerea isolates tested showed different levels of resistance toward thiophanate-methyl, and the HR isolates detected were not controlled after inoculations on detached grape berries pretreated with thiophanate-methyl. Similarly, B. cinerea isolates from table grapes grown in the San Joaquin Valley of California were shown to have different levels of resistance to thiophanate-methyl (Smilanick et al. 2010). Among other fungicides, thiophanate-methyl was the least effective as both a protective and a curative treatment when applied to detached cultivar Thompson Seedless berries treated before or after inoculation with $B$. cinerea in laboratory experiments (Smilanick et al. 2010). The high frequencies of thiophanate-methyl-resistant isolates observed in our study confirm a long-time occurrence and persistence of benzimidazole resistance long after the withdrawal of these fungicides as was shown in other fungal populations, even in the absence of benzimidazole use for periods in excess of 5 years (Koch et al. 2009). Thiophanate-methyl is also recommended as a bloom spray against the Botryosphaeria panicle and shoot blight of pistachio (Adaskaveg et al. 2017). Because this fungicide can reduce this disease by $50 \%$, pistachio growers have been using it every year. Although Botrytis blossom and shoot blight does not occur every year, regular applications of thiophanate-methyl to control the severe Botryosphaeria panicle and shoot blight may be another factor contributing and maintaining a strong selection pressure on Botrytis benzimidazole-resistant populations in pistachio.

Notably, although 7 and 1\% levels of the grape and pistachio isolates, respectively, were sensitive to thiophanate-methyl, none of the pomegranate isolates were sensitive. In fact, all pomegranate isolates were classified as either HR or LR, and they were collected from orchards that had no history of benzimidazole applications. Our results suggest that resistance to thiophanate-methyl is present in pomegranate orchards, although no thiophanate-methyl against gray mold is applied in California pomegranate orchards. Most of the $B$. cinerea isolates classified as thiophanate-methyl resistant in this study originated from areas where pistachio orchards and grape vineyards received an intensive application of benzimidazole fungicides. The occurrence of resistant phenotypes in pomegranates may be because of aerial movement of resistant isolates originating from these pistachio or grape crops, which are grown close to pomegranate orchards in many areas in California. Migration of fenhexamid-resistant $B$. cinerea isolates from other hosts with approximately a 20 -fold increase in resistance to fenhexamid, a specific hydroxyanilide fungicide for gray mold control (Leroux et al. 2002a, b), has been demonstrated in fig trees, although this fungicide had never been sprayed in these trees (Ma and Michailides 2005b).

The mutation detected in this study could be useful in epidemiological studies examining movement of $B$. cinerea from different hosts. Considering the stability and widespread occurrence of thiophanate-methyl resistance, this fungicide should not be used or should be used with caution for gray mold and Botrytis blossom and shoot blight controls in California grape vineyards and pistachio orchards where resistance has been confirmed. With the availability of alternative botryticides, such as the quinone outside inhibitors, succinate dehydrogenase inhibitors, or hydroxyanilide (Adaskaveg et al. 2017; Myresiotis et al. 2007), commercial pistachio and grape growers in California have indeed relied on newer classes of fungicides for control of these diseases.

\section{Acknowledgments}

We thank Michael Luna and Ryan D. Puckett for technical assistance.

\section{Literature Cited}

Adaskaveg, J. E., Michailides, T. J., and Gubler, W. D. 2017. Efficacy and Timing of Fungicides, Bactericides, and Biologicals for Deciduous Tree Fruit, Nut, Strawberry, and Vine Crops. http://ipm.ucanr.edu/PDF/PMG/fungicideefficacytiming.pdf 
Albertini, C., Gredt, M., and Leroux, P. 1999. Mutations of the b tubulin gene associated with different phenotypes of benzimidazole resistance in the cereal eyespot fungi Tapesia yallundae and Tapesia acuformis. Pestic. Biochem. Physiol. 64:17-31.

Avenot, H. F., Quattrini, J., Puckett, R., and Michailides, M. J. 2018. Different levels of resistance to cyprodinil and iprodione and lack of fludioxonil resistance in Botrytis cinerea isolates collected from pistachio, grape, and pomegranate fields in California. Crop Prot. 112:274-281.

Billard, A., Fillinger, S., Leroux, P., Bach, J., Lanen, C., Lachaise, H., Beffa, R., and Debieu, D. 2011. Fenhexamid resistance in the Botrytis species complex, responsible for grey mould disease. Pages 61-78 in: Fungicides-Beneficial and Harmful Aspects. N. Thajuddin, ed. InTech Publisher, Rijeka, Croatia.

Bolkan, H. A., Ogawa, J. M., and Teranishi, H. R. 1984. Shoot blight of pistachio caused by Botrytis cinerea. Plant Dis. 68:163-165.

Brent, K. J., and Hollomon, D. W. 1998. Fungicide resistance: The assessment of risk. FRAC Monograph No. 2. FRAC, Brussels, Belgium.

Cunha, M. G., and Rizzo, D. M. 2003. Development of fungicide cross-resistance in Helminthosporium solani populations from California. Plant Dis. 87:798-803.

Davidse, L., and Ishii, T. 1995. Biochemical and molecular aspects of benzimidazoles, $\mathrm{N}$-phenylcarbamates and $\mathrm{N}$-phenylformamidoxines and the mechanisms of resistance to these compounds in fungi. Pages 305-322 in: Modern Selective Fungicides. H. Lyr, ed. Gustav Fisher, Jena, Germany.

De Waard, M. A., Georgopoulos, S. G., Hollomon, D. W., Ishii, H., Leroux, P., Ragsdale, N. N., and Schwinn, F. J. 1993. Chemical control of plant diseases: Problems and prospects. Annu. Rev. Phytopathol. 31:403-421.

Du Pont. 1988. Benlate ${ }^{\circledR} 50$ DF fungicide control of shoot blight on pistachio in the State of California. Supplemental Bulletin. EPA Reg. No. 352-447. Agricultural Bulletin. E. I. DuPont de Nemours \& Co. Agricultural Products Department, Wilmington, DE, USA.

Elmer, P. A. G., and Michailides, T. J. 2004. Epidemiology of Botrytis cinerea in orchard and vine crops. Pages 243-272 in: Botrytis: Biology, Pathology and Control. Y. Elad, B. Williamson, P. Tudzynski, and N. Delen, eds. Springer, Dordrecht, The Netherlands.

Fungicide Resistance Action Committee. 2012. FRAC List of Plant Pathogenic Organisms Resistant to Disease Control Agents. https://www.frac.info/docs/ default-source/working-groups/sdhi-fungicides/group/list-of-resistant-plant-pathogens_ 2012-edition.pdf

Georgopoulos, S. G., and Skylakakis, G. 1986. Genetic variability in the fungi and the problem of fungicide resistance. Crop Prot. 5:299-305.

Keinath, A. P. 2002. Survival of Didymella bryoniae in buried watermelon vines in South Carolina. Plant Dis. 86:32-38.

Koch, P. L., Grau, C. R., Jo, Y.-K., and Jung, G. 2009. Thiophanate-methyl and propiconazole sensitivity in Sclerotinia homoeocarpa populations from golf courses in Wisconsin and Massachusetts. Plant Dis. 93:100-105.

Koenraadt, H., Somerville, S. C., and Jones, A. L. 1992. Characterization of mutations in the beta-tubulin gene of benomyl-resistant field strains of Venturia inaequalis and other plant pathogenic fungi. Phytopathology 82:1348-1354.

Leroux, P. 2004. Chemical control of Botrytis and its resistance to chemical fungicides. Pages 195-222 in: Botrytis: Biology, Pathology and Control. Y. Elad, B. Williamson, P. Tudzynski, and N. Delen, eds. Springer, Dordrecht, The Netherlands.

Leroux, P., Debieu, D., Albertini, C., Arnold, A., Bach, J., Chapeland, F., Fournier, E., Fritz, R., Gredt, M., Giraud, T., Hugon, M., Lanen, C., Malosse, C., and Thebaud, G. 2002a. The hydroxyanilide botryticide fenhexamid/mode of action and mechanism of resistance. Pages 29-40 in: Modern Fungicides and Antifungal Compounds III. Proceedings of the 13th International Reinhardsbrunn Symposium. H. W. Dehne, H. B. Deising, U. Gisi, K. H. Kuck, P. E. Russell, and H. Lyr, eds. AgroConcept GmbH, Bonn, Germany.

Leroux, P., Fritz, R., Debieu, D., Albertini, C., Lanen, C., Bach, J., Gredt, M., and Chapeland, F. 2002b. Mechanisms of resistance to fungicides in field strains of Botrytis cinerea. Pest Manag. Sci. 58:876-888.
Luo, Y., Ma, Z., and Michailides, T. 2007. Quantification of allele E198A in betatubulin conferring benzimidazole resistance in Monilinia fructicola using realtime PCR. Pest Manag. Sci. 63:1178-1184.

Ma, Z., and Michailides, T. J. 2005a. Advances in understanding molecular mechanisms of fungicide resistance and molecular detection of resistan genotypes in phytopathogenic fungi. Crop Prot. 24:853-863.

Ma, Z., and Michailides, T. J. 2005b. Genetic structure of Botrytis cinerea populations from different host plants in California. Plant Dis. 89:1083-1089.

Ma, Z., Yoshimura, M., and Michailides, T. J. 2003. Identification and characterization of benzimidazole resistance in Monilinia fructicola from stone fruit orchards in California. Appl. Environ. Microbiol. 69:7145-7152.

Michailides, T. J. 1991. Susceptibility of pistachio male cultivars to botrytis blossom and shoot blight caused by Botrytis cinerea. Plant Dis. 75:410-415.

Myresiotis, C. K., Karaoglanidis, G. S., and Tzavella-Klonari, K., 2007. Resistance of Botrytis cinerea isolates from vegetable crops to anilinopyrimidine, phenylpyrrole, hydroxyanilide, benzimidazole, and dicarboximide fungicides. Plant Dis. 91:407-413.

Ott, A. 2004. Emergency exemption petition for the post-harvest use of fludioxonil (scholar fungicide) on pomegranates in the southern San Joaquin Valley of California. California Department of Pesticide Regulation and the United States Environmental Protection Agency, Sacramento, CA, USA.

Palou, L., Taberner, V., Guardado, A., Del Río, M. A., and Montesinosherrero, C. 2013. Incidence and etiology of postharvest fungal diseases of pomegranate (Punica granatum cv. Mollar de Elche) in Spain. Phytopathol. Mediterr. 52: 478-489.

Panebianco, A., Castello, I., Cirvilleri, G., Perrone, G., Epifani, F., Ferrara, M., Polizzi, G., Walters, D. R., and Vitale, A. 2015. Detection of Botrytis cinerea field isolates with multiple fungicide resistance from table grape in Sicily. Crop Prot. 77:65-73.

Schüepp, H., and Küng, M. 1981. Stability of tolerance to MBC in populations of B. cinerea in vineyards of northern and Eastern Switzerland. Can. J. Plant Pathol. 3:180-181.

Smilanick, J. L., Mansour, M. F., Mlikota Gabler, F., Margosan, D. A., and Hashim-Buckey, J. 2010. Control of postharvest gray mold of table grapes in the San Joaquin Valley of California by fungicides applied during the growing season. Plant Dis. 94:250-257.

Staub, T. 1991. Fungicide resistance: Practical experience with anti-resistance strategies and the role of integrated use. Annu. Rev. Phytopathol. 29: 421-442.

Stehmann, C., and De Waard, M. 1996. Sensitivity of populations of Botrytis cinerea to triazoles, benomyl and vinclozolin. Eur. J. Plant Pathol. 102: 171-180.

Tedford, E., Adaskaveg, J., and Ott, A. 2005. Impact of Scholar (a new postharvest fungicide) on the California pomegranate industry. Plant Health Prog. https://doi.org/10.1094/PHP-2005-0216-01-PS

Teviotdale, B., Adaskaveg, J. E., Michailides, T. J., and Gubler, W. D. 2002 Fungicide Efficacy and Timing for Deciduous Fruit and Nut Tree Crops and Grapevines. http://kare.ucanr.edu/files/90319.pdf

Topolovec-Pintarić, S. 2011. Resistance to Botryticides. Pages 19-44 in: Fungicides-Beneficial and Harmful Aspects. N. Thajuddin, ed. InTech Publisher, Rijeka, Croatia

Wong, F. P., de la Cerda, K. A., Hernandez-Martinez, R., and Midland, S. L. 2008 Detection and characterization of benzimidazole resistance in California populations of Colletotrichum cereale. Plant Dis. 92:239-246.

Yarden, O., and Katan, T. 1993. Mutations leading to substitutions at amino acid 198 and 200 of beta-tubulin that correlate with benomyl-resistant phenotypes of field strains of Botrytis cinerea. Phytopathology 83:1478-1483.

Ziogas, B. N., Nikou, D., Markoglou, A. N., Malandrakis, A. A., and Vontas, J. 2009. Identification of a novel point mutation in the $\beta$-tubulin gene of Botrytis cinerea and detection of benzimidazole resistance by a diagnostic PCR-RFLP assay. Eur. J. Plant Pathol. 125:97-107. 